\title{
P̈̈̈̈KIRJOITUS
}

\section{AVOIMESTI SUOMEKSI - MAHDOTON YHTÄLÖ?}

$\mathrm{T}$

UTKIJAA OHJAA TYÖSSÄÄN - sisäisen totuudenpalon lisäksi - tarve turvata oma työllisyys tutkijana ja ura yliopistojen ja tutkimuslaitosten hierarkioissa. Näissä instituutioissa kansainvälistä, englanninkielistä, julkaisemista arvostetaan enemmän kuin suomenkielistä.

Suomessa työskentelevän tutkijan on oman uran kannalta välttämätöntä julkaista kansainvälisillä foorumeilla. Pelkästään suomeksi kirjoittavat tutkija jäävät työpaikkakilpailussa englanniksi kirjoittavien kollegoiden jalkoihin. Toki tutkijaa motivoi myös yleisö: englanninkielisen artikkelin potentiaalinen lukijakunta voi olla monisatakertainen suomea lukeviin verrattuna.

Helsingin yliopiston professori Kari Enqvis kirjoitti Helsingin Sanomissa 11. helmikuuta, että tutkijoilla ei ole mitään velvollisuuksia suomen kieltä kohtaan. Kun tutkimuksen lukijoina on vain kosmologien rajallinen joukko, kielikysymys on epäolennainen. Mutta kun kosmologit kirjoittavat yleistajuisia tietokirjoja suomeksi, heitä luetaa ahkerasti. Kaikilla tieteenaloilla tulosten välimatk tutkimusartikkelista tekstiksi lukevan yleisön käsii ei ole yhtä pitkä. Esimerkiksi humanistisissa ja yhteiskuntatieteissä on mahdollista kirjoittaa kielellä, josta keskivertovalistunut kansalainenkin saa aineksia ajatteluuns
KYSYMYKSEEN SUOMENKIELISEN TIETEEN tarpeellisuudesta ei ole mielekästä vastata joko kyllä tai ei. Tiede ei ole monoliitti. Tutkimusta tehdään tieteenaloittain, ja eri alojen suhde kieleen ja tutkittavaan todellisuuteen on kovin erilainen. Tutkijat Hannu LT. Heikkinen ja Tuukka Tomperi analysoivat Kasvatuslehdessä (2/2018) tieteen kielikysymystä aikuiskasvatuksen kaltaisilla aloilla seuraavasti:

"Mitä vahvemmin tutkimus kohdistuu erityisiin sosiokulttuurisiin ilmiöihin, sitä enemmän tulkitaan merkityksiä ja sitä merkityksellisemmäksi tulee tutkimuksen kieli. Kielellä on merkitystä tutkimuksen kaikissa vaiheissa aineiston keruusta ja analyysist päätelmiin, raportointiin ja viestintään. Tutkimusaineistoissa tai koko tutkimuskohteen teoreettisess ymmärtämisessä saatetaan käyttää termistöä, joka ei käännettynä hahmotu oikein. Kielen vaikutus havait semiseen ja todellisuuden jäsentämiseen on erityisen tärkeätä tunnistaa - ja tunnustaa - tutkimusaloill jotka keskittyvät ihmisten ajattelu- ja puhetapoihin sekä maailmankuviin."

Yksittäisellä tutkijalla ei varmaan olekaan velvollisuuksia sen enempää suomea kuin muitakaan kielia kohtaan. Mutta ihmistieteiden piirissä harva ajattelee, että suomen kielellä julkaiseminen joutaisi lopettaa. Pikemminkin päätellään, että yhteiskunnalle ja kulttuurille on hyväksi käyttää kotimaisia kieliä myös tieteessä ja tehdä tutkimusta suomeks
OPETUS- JA KULTTUURIMINISTERIÖ ON VIRITTÄNYT TUTKIJOILLE ORAVANPYÖRÄN, JONKA VAUHTIA TUTKIMUKSEN TEKIJÄT ITSE EIVÄT VOI KOHTUULLISTAA.
Ihmistieteilijät itse ovat suomen puolestapuhujina valtiovaltaa aktiivisempia. Kun opetus- ja kulttuuriministeriö (OKM) otti vuosikymmenen alussa yliopistojen rahoituksen yhdeksi kriteeriksi Tieteellisten seurain valtuuskunnan julkaisufoorumihankkeen (JUFO) luokitukset, lähtökohtana oli, että suomenkieliset lehdet eivät ansaitse tulla arvioiduksi alinta tasoa korkeammalle lukuun ottamatta historian tutkimuksen Historiallista aikakauskirjaa ja suomen kielen Virittäjäë Vasta tieteellisten seurojen kannanoton vaikutuksesta linjaus peruttiin (ks. Aikuiskasvatus 1/2012). Tällä hetkellä tasolla 2 on 16 suomenkielistä lehteä.

JUFO-luokituksissa näkyvä edistys on pikemminkin kielipoliittista kuin tieteellistä. Luokitusjärjestelmää ei nimittäin ensisijaisesti luotu julkaisukanavien tieteellisen tason määrittämiseksi vaan yliopistojen rahoituksen jakamista varten. Tätä nykyä 13 prosenttia yliopistojen rahoituksesta jaetaan sen perusteella kuinka paljon kukin yliopisto on tuottanut julkaisuja. Yliopistojen keskinäinen kilpailu tuosta rahoitusosuudesta on nollasummapeliä: jaettava summa ei suurene senttiäkään, vaikka julkaisumäärä miten kasvaa. Kilpailu vain kovenee.

OKM on virittänyt tutkijoille oravanpyörän, jonka vauhtia tutkimuksen tekijät itse eivät voi kohtuullistaa, elleivät yliopistot keskenään sovi kartellia julkaisutuotantoon. Vain julkaisumääristä sovittu kartell toisi tutkijoille aikaa luovaan ajatteluun ja julkaisujen tieteellisen tason parantamiseen. JUFO-järjestelmää käytetään sumeilematta myös tutkijoiden arvioimiseen, ja se on omiaan paineistamaan tutkimustyötä.
TIETEELLISEEN JULKAISEMISEEN olisi syytä hieroa kielirauha. Englannin asemaa tieteen kielenä ei uhkaa mikään: marginaalisen kielialueen tutkijat eivät halua jäädä kansainvälisen tieteen marginaaliin, ja valtiovalta kannustaa rahan avulla yliopistoja kansainvälistämään julkaisutoimintaa. Lisäksi se kannusta tutkijoita suosimaan avoimia julkaisukanavia. Mikä ministeriölle lokakuussa 2018 jätetty ehdotus yliopistojen uudeksi rahoitusmalliksi toteutetaan, open access -lehdissä julkaistut artikkelit saavat maksullisi julkaisuja suuremman painoarvon: ne arvioidaan kertoimella 1,2. Paine avoimeen tieteelliseen julkaisemiseen kasvaa entisestään.

Aikuiskasvatus muuttuu avoimesti verkosta saavaksi vuoden 2019 alusta. Samaa päätöstä puntarovat muutkin tiedelehdet. Miten pidetään yllä lehteä joka ei saa tuloja tilausmaksuista, on kysymys avoimuuden tiellä. Kaikki julkaiseminen vaatii resursseja. Talkootyö kuuluu menneeseen maailmaan. Yliopistoissa työskentelevien suoritteiden arvottava mittaaminen on rapauttanut vapaaehtoistyön edellytyksiä. Kuuliainen yliopistotutkija tekee sitä, mitä mitataan.

Valtiovalta suhtautuu oudon välinpitämättömästi suomenkieliseen tiedejulkaisemiseen. Päätöksentekijät eivät tunnu ymmärtävän kotimaisilla kielillä tehdyn tieteen ja väestön sivistystason keskinäistä yhteyttä. Tieteellisten julkaisujen saattaminen avoimiksi edellyttää ennustettavasti järjestettyä rahoitusta. Ministeriön olisi korkea aika aktivoitua asiassa.

Heikki Silvennoinen 